Article

\title{
Evolution of Public Health Human Papillomavirus Immunization Programs in Canada
}

\author{
Alexandra Goyette ${ }^{1, *}$, Glorian P. Yen ${ }^{2}{ }^{\mathbb{D}}$, Voica Racovitan ${ }^{1}$, Parambir Bhangu ${ }^{1}$, Smita Kothari ${ }^{2}$ \\ and Eduardo L. Franco ${ }^{3}$ \\ 1 Merck Canada Inc., Kirkland, QC H9H 4M7, Canada; voica.racovitan@merck.com (V.R.); \\ parambir.bhangu@merck.com (P.B.) \\ 2 Merck \& Co., Inc., Kenilworth, NJ 07033, USA; glorian.persaud.yen@merck.com (G.P.Y.); \\ smita.kothari@merck.com (S.K.) \\ 3 Division of Cancer Epidemiology, McGill University, Montreal, QC H4A 3T2, Canada; \\ eduardo.franco@mcgill.ca \\ * Correspondence: alexandra.goyette@merck.com; Tel.: +1-514-428-3092
}

Academic Editor: Marco Iafolla

Received: 13 November 2020; Accepted: 5 February 2021; Published: 22 February 2021

check for updates

\begin{abstract}
Background: Since 2007, all Canadian provinces and territories have had a publicly funded program for vaccination against human papillomavirus (HPV) infection. The objective of this study was to describe the evolution of these vaccination programs. Methods: This was a targeted literature review of public HPV vaccination programs and vaccination coverage rates, based on information provided by jurisdictional public health authorities. Results: HPV vaccination of schoolgirls began in school years 2007/08 to 2010/11 with three doses of the quadrivalent HPV vaccine in all provinces except Quebec, which started with two doses. By 2018/19, all jurisdictions were vaccinating with two doses of the nonavalent vaccine in both girls and boys, except Quebec, which used a mixed vaccination schedule with one dose of the nonavalent and one dose of the bivalent vaccines. Public HPV vaccination programs in most provinces include after-school catch-up vaccination. Immunocompromised or other high-risk individuals are eligible for the HPV public vaccination program in most provinces, but policies vary by jurisdiction. In 2017/18, vaccination coverage rates in provincial HPV school-based programs varied from $62 \%$ in Ontario to $86 \%$ in Prince Edward Island in girls and from $58 \%$ in Ontario to $86 \%$ in Prince Edward Island in boys. Conclusions: Since their introduction, Canadian school-based HPV public vaccination programs have evolved from a three-dose to a two-dose schedule, from a quadrivalent to a nonavalent vaccine, and from a girls-only to a gender-neutral policy. Vaccination coverage rates have varied markedly and only Prince Edward Island and Newfoundland/Labrador have maintained rates exceeding $80 \%$.
\end{abstract}

Keywords: human papillomavirus; public health programs; Canada; vaccination; vaccine policy; school health services

\section{Introduction}

Human papillomavirus (HPV) is a sexually transmitted infection [1], with more than 200 genetically distinct types (i.e., strains) of HPV [2]. HPV types have been classified by the International Agency for Research on Cancer as per their carcinogenicity [3]. HPV types 16, 18, 31, 33, 35, 39, 45, 51, 52, 56, 58, and 59 are considered carcinogenic, whereas HPV 68 is considered probably carcinogenic. Several other types are considered possibly carcinogenic, i.e., HPVs $26,30,34,53,66,67,69,70,73,82,85$, and 97 [3]. A few other HPV types, such as 6, 11, 42, 43, and 44, cause benign lesions or asymptomatic infections [2]. Infection with carcinogenic HPV types can lead to cervical, anal, vaginal, vulvar, penile, 
and oropharynx cancers [1]. Vaccination against human papillomavirus infection could potentially eliminate the most important HPV types that cause cervical, anogenital, and oropharyngeal cancers [4].

Canada was one of the first countries to implement a publicly funded HPV vaccination program. Three vaccines to protect against carcinogenic strains of HPV have been licensed in Canada [5,6]. First, a quadrivalent vaccine (4vHPV) targeting HPV types 6, 11, 16, and 18 was approved in 2006 for use in females 9 to 26 years of age and in 2010 for use in males 9 to 26 years of age. In 2011, the indication was further extended to include women up to 45 years of age. Second, a bivalent vaccine (2vHPV) protecting against types 16 and 18 was approved for females in 2010. Finally, a nonavalent vaccine (9vHPV) targeting carcinogenic types 16, 18, 31, 33, 45, 52, and 58 and low-risk types 6 and 11 was approved for both females and males in 2015.

Figure 1 shows the 10 provinces and 3 territories in Canada. Each province and territory is responsible for implementing its public HPV vaccination program. While each jurisdictional program has undergone a series of policy changes, program information is scattered across multiple sources and there is no national database that compiles this information. There have been several descriptions of HPV vaccination programs [5-8], but no analysis of the evolution of HPV vaccination policies and vaccination coverage in all Canadian jurisdictions. As Canada prepares to implement the prevention strategies designed to meet the World Health Organization's goal of eliminating cervical cancer [8], it is essential that Canadian policymakers take stock of the current status of HPV vaccination. Hence, the objective of this study is to synthesize publicly available information for each jurisdiction and to describe the evolution of public HPV vaccination programs in Canada.

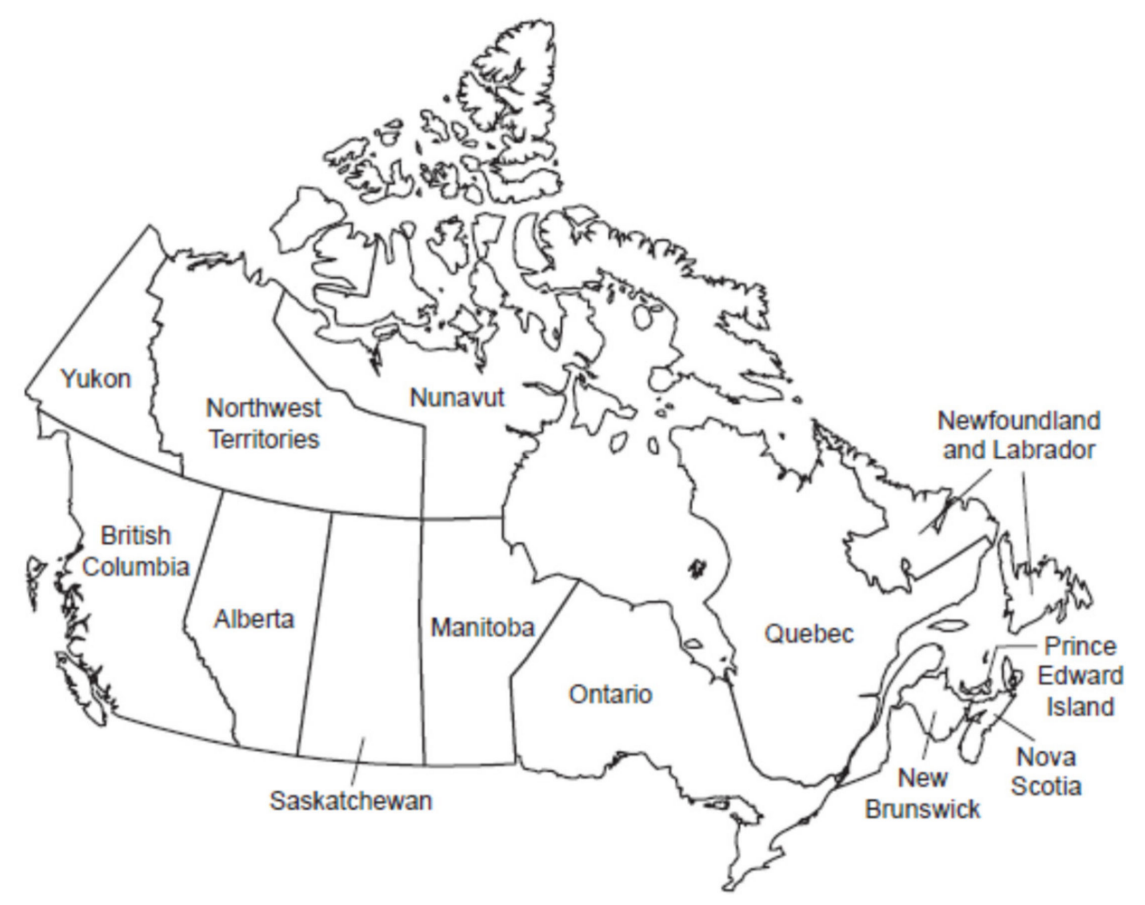

Figure 1. Map of Canada with provinces and territories.

\section{Methods}

This was a targeted literature review of HPV vaccination programs in Canada, focused on governmental databases and statistics, informal reports, Embase, and PubMed. The scope of the searches was based on the PICO (+) framework (population, interventions, comparisons, outcomes, and time) described in Supplementary Table S1. Searches were conducted between 29 August 2019 and 12 September 2019. We searched the websites of Canadian provincial and territorial health public health authorities with keywords in English and French related to public HPV vaccination programs and 
vaccination coverage rates. Specific search terms were customized to each province/territory. Examples of search terms are "HPV immunization AND name of province/territory", "HPV immunization program AND name of province/territory", "HPV eligibility AND name of province/territory", "HPV vaccine coverage AND name of province/territory", "immunization coverage AND name of province/territory", "immunization coverage report AND name of province/territory", "immunization report AND name of province/territory", "immunization coverage AND school AND name of province/territory", and "vaccine coverage AND name of province/territory". In addition, we conducted searches of the peer-reviewed literature. PubMed was searched in a heuristic approach, involving chain-searching of related and citing articles. Articles reporting HPV-related studies in Canada were retrieved. Where information was not located using the published literature, local provincial health authorities were directly contacted.

\section{Data Analysis}

We retrieved information by province/territory on the publicly funded, school-based primary grade(s) covered for vaccination, temporary catch-up cohorts, if the programs covered girls and boys, year of program introduction, vaccination schedule, and vaccine coverage rate by year and sex, where published and available. Birth year of children eligible for school-based vaccination programs and other groups eligible for public HPV vaccination programs was also extracted when available. Program details were synthesized by province/territory and year, including vaccination schedule and vaccination coverage rate by sex, and are presented together over time.

All available vaccine coverage rate data were extracted; however, this paper only presents vaccine coverage rates for cohorts that received the full course of HPV vaccination based on the recommended dose regimen at the time of administration.

When not available, birth year of children eligible for school-based vaccination programs was calculated using the assumption that children are five years old when they start kindergarten. For example, if girls and boys are eligible for vaccination in Grade 6 for the 2017/18 school year, it was assumed that they were 11 years old when they were eligible for the first dose of HPV vaccine and it was calculated that the birth year of this cohort was 2006 (2017-11).

Vaccination coverage rate (as a percentage) is expressed as the number of children vaccinated relative to the number eligible for vaccination.

\section{Ethics Approval}

This was a review of publicly available aggregate data and information from published literature; therefore, ethical approval was not required.

\section{Results}

\subsection{Evolution of Public HPV Vaccination Programs}

As shown in Table 1, between school years 2007/08 and 2010/11, all Canadian jurisdictions initiated school-based HPV vaccination for girls within their publicly funded immunization programs. All jurisdictions began with a three-dose schedule (0,2, and 6 months) of 4vHPV in Grades 6 or 7 (Grades 4-6 in Northwest Territories) except Quebec. In Quebec, the HPV program began with two doses ( 0 and 6 months) in Grade 4, with a third dose scheduled to be received in Grade 9, five years later. However, in 2013, the program was changed to remove the third dose before the first cohort vaccinated reached Grade 9. In consequence, girls in Quebec have always received two doses, six months apart. Similarly, in British Columbia, the initial three-dose schedule for girls in Grade 6 was changed in 2010 to a two-dose schedule in Grade 6, with a third dose scheduled in Grade 9. The British Columbia program was changed to a two-dose schedule in 2014. Therefore, only the cohort vaccinated in 2010/11 had their third dose in Grade 9; all other cohorts vaccinated after 2010 received two doses. Subsequently, all programs except Alberta transitioned to a two-dose schedule of 4vHPV and then a two-dose 
schedule of 9vHPV. Alberta was one of the first provinces to transition to 9vHPV vaccine in 2016 and remained at a three-dose 9vHPV scheme until 2018, when the province moved to a two-dose schedule. By the 2018/19 school year, all HPV programs for the 13 Canadian jurisdictions were using a two-dose schedule of the 9vHPV, except Quebec, which adopted in that year a mixed schedule approach with a first dose of 9vHPV followed by 2vHPV for the second dose 6 months later. As of September 2020, Quebec divulged plans to defer the second dose to 5 years later.

In 2013/14, Prince Edward Island was the first province to include boys in the school-based vaccination program. Alberta followed in 2014/15 and Nova Scotia in 2015/16 [9]. All other provinces implemented gender-neutral programs in 2016/17 or 2017/18. By 2018/19, all jurisdictions had gender-neutral, school-based programs with a two-dose schedule of 9vHPV offered in Grades 4 to 7 , except that Quebec had a two-dose mixed schedule.

As shown in Table 2, eight of the 13 Canadian jurisdictions instituted a temporary catch-up vaccination program for schoolgirls at either the first or second year of the inception of the program for varying lengths of time (between 1 and 5 years). In 2016, Ontario changed the target age of its vaccination program from Grade 8 to 7 and added one additional cohort so girls in Grade 8 would not be missed during the transition. Alberta, Manitoba, and Quebec were the only provinces that implemented temporary catch-up programs lasting 3 or 4 years for schoolboys at the first or at the second year post program inception. Table 3 shows the birth years of children that have been eligible for the school-based HPV vaccination programs since the introduction of the programs up to the end of the 2019/20 school year.

In addition to the school-based programs, in most of the jurisdictions, individuals who missed the full course while at school remained eligible, as shown in Table 4. Finally, most jurisdictions have public HPV vaccination programs for high-risk groups, which comprise men who have sex with men, transsexual persons, HIV-infected individuals, and other at-risk groups (Table 4). 
Table 1. Evolution of school-based public HPV vaccination programs and vaccination coverage rates.

\begin{tabular}{|c|c|c|c|c|c|c|c|c|c|c|c|c|c|c|}
\hline \multirow{2}{*}{ Province/territory } & \multirow{2}{*}{$\begin{array}{l}\text { School Grade of } \\
\text { Vaccination }\end{array}$} & & \multicolumn{12}{|c|}{ School year } \\
\hline & & & $2007 / 08$ & $2008 / 09$ & $2009 / 10$ & $2010 / 11$ & 2011/12 & $2012 / 13$ & $2013 / 14$ & $2014 / 15$ & $2015 / 16$ & 2016/17 & $2017 / 18$ & $2018 / 19$ \\
\hline \multirow[b]{2}{*}{ British Columbia $^{\text {a }}$} & \multirow[b]{2}{*}{ Grade 6} & Girls & & $61.9 \%$ & $59.9 \%$ & $64.3 \%$ & $68.7 \%$ & $68.8 \%$ & $65.8 \%$ & $64.8 \%$ & $67.1 \%$ & $66.5 \%$ & $66.9 \%$ & $66.1 \%$ \\
\hline & & Boys & & & & & & & & & & & $64.6 \%$ & $63.5 \%$ \\
\hline \multirow{2}{*}{ Alberta ${ }^{b}$} & \multirow{2}{*}{ Grade 6} & Girls & & $54.2 \%$ & $55.7 \%$ & $58.6 \%$ & $59.9 \%$ & $62.2 \%$ & $62.6 \%$ & $64.2 \%$ & $63.9 \%$ & $63.6 \%$ & $68.2 \%$ & $\mathrm{~N} / \mathrm{A}$ \\
\hline & & Boys & & & & & & & & $60.3 \%$ & $62.9 \%$ & $63.6 \%$ & $66.1 \%$ & $\mathrm{~N} / \mathrm{A}$ \\
\hline \multirow{2}{*}{ Saskatchewan ${ }^{c}$} & \multirow{2}{*}{ Grade 6} & Girls & & $74.5 \%$ & $76.6 \%$ & $72.7 \%$ & $73.5 \%$ & $72.8 \%$ & $68.7 \%$ & $61.4 \%$ & $69.1 \%$ & $69.1 \%$ & N/A & N/A \\
\hline & & Boys & & & & & & & & & & & N/A & $\mathrm{N} / \mathrm{A}$ \\
\hline \multirow{2}{*}{ Manitoba ${ }^{\mathrm{d}}$} & \multirow{2}{*}{ Grade 6} & Girls & & $57.6 \%$ & $57.0 \%$ & $62.0 \%$ & $62.7 \%$ & N/A & $67.3 \%$ & $68.5 \%$ & $65.0 \%$ & N/A & N/A & $\mathrm{N} / \mathrm{A}$ \\
\hline & & Boys & & & & & & & & & & N/A & N/A & $\mathrm{N} / \mathrm{A}$ \\
\hline \multirow{2}{*}{ Ontario $^{\mathrm{e}}$} & \multirow{2}{*}{ Grade 7} & Girls & $48.0 \%$ & $52.5 \%$ & $55.2 \%$ & $58.4 \%$ & $70.2 \%$ & $80.2 \%$ & $61.5 \%$ & $60.4 \%$ & $61.0 \%$ & $59.4 \%$ & $62.4 \%$ & $\mathrm{~N} / \mathrm{A}$ \\
\hline & & Boys & & & & & & & & & & $53.4 \%$ & $57.5 \%$ & $\mathrm{~N} / \mathrm{A}$ \\
\hline \multirow{2}{*}{ Quebec ${ }^{\mathrm{f}}$} & \multirow{2}{*}{ Grade 4} & Girls & & $81.0 \%$ & $76.0 \%$ & $78.0 \%$ & $77.0 \%$ & $78.0 \%$ & $77.0 \%$ & $74.0 \%$ & $73.0 \%$ & $76.0 \%$ & $77.0 \%$ & $79.0 \%$ \\
\hline & & Boys & & & & & & & & & & $72.0 \%$ & $74.0 \%$ & $77.0 \%$ \\
\hline \multirow{2}{*}{ New Brunswick } & \multirow{2}{*}{ Grade 7} & Girls & & $72.8 \%$ & $71.2 \%$ & $73.0 \%$ & $75.8 \%$ & $75.1 \%$ & $73.0 \%$ & $73.5 \%$ & $75.4 \%$ & $74.7 \%$ & $74.8 \%$ & $74.9 \%$ \\
\hline & & Boys & & & & & & & & & & & $70.2 \%$ & $72.8 \%$ \\
\hline \multirow{2}{*}{ Nova Scotia $g$} & \multirow{2}{*}{ Grade 7} & Girls & N/A & $77.1 \%$ & $59.8 \%$ & $74.8 \%$ & $76.1 \%$ & $77.2 \%$ & $75.0 \%$ & $75.6 \%$ & $80.8 \%$ & $73.4 \%$ & $\mathrm{~N} / \mathrm{A}$ & N/A \\
\hline & & Boys & & & & & & & & & $81.0 \%$ & $84.9 \%$ & $\mathrm{~N} / \mathrm{A}$ & $\mathrm{N} / \mathrm{A}$ \\
\hline \multirow{2}{*}{ Prince Edward Island } & \multirow{2}{*}{ Grade 6} & Girls & N/A & $81.1 \%$ & $\mathrm{~N} / \mathrm{A}$ & N/A & $85.1 \%$ & $87.3 \%$ & $84.9 \%$ & $82.7 \%$ & $84.3 \%$ & $88.4 \%$ & $86.4 \%$ & $84.0 \%$ \\
\hline & & Boys & & & & & & & $79.0 \%$ & $81.4 \%$ & $85.0 \%$ & $89.7 \%$ & $85.6 \%$ & $82.1 \%$ \\
\hline \multirow{2}{*}{ Newfoundland/Labrador } & \multirow{2}{*}{ Grade 6} & Girls & $83.7 \%$ & $88.2 \%$ & $84.6 \%$ & $90.6 \%$ & $86.1 \%$ & $94.3 \%$ & $88.7 \%$ & $89.2 \%$ & $92.0 \%$ & N/A & N/A & N/A \\
\hline & & Boys & & & & & & & & & & & N/A & N/A \\
\hline \multirow{2}{*}{ Yukon } & \multirow{2}{*}{ Grade 6} & Girls & & & N/A & N/A & $\mathrm{N} / \mathrm{A}$ & N/A & N/A & N/A & N/A & $66.5 \%$ & N/A & N/A \\
\hline & & Boys & & & & & & & & & & & $\mathrm{N} / \mathrm{A}$ & N/A \\
\hline
\end{tabular}


Table 1. Cont.

\begin{tabular}{|c|c|c|c|c|c|c|c|c|c|c|c|c|c|c|}
\hline \multirow{2}{*}{ Province/territory } & \multirow{2}{*}{$\begin{array}{l}\text { School Grade of } \\
\text { Vaccination }\end{array}$} & & \multicolumn{12}{|c|}{ School year } \\
\hline & & & $2007 / 08$ & 2008/09 & $2009 / 10$ & 2010/11 & $2011 / 12$ & $2012 / 13$ & 2013/14 & $2014 / 15$ & $2015 / 16$ & 2016/17 & 2017/18 & 2018/19 \\
\hline \multirow{2}{*}{ Northwest Territories $h$} & \multirow{2}{*}{ Grades $4-6$} & Girls & & & N/A & N/A & N/A & N/A & $39.3 \%$ & N/A & $55.0 \%$ & N/A & N/A & N/A \\
\hline & & Boys & & & & & & & & & & & N/A & N/A \\
\hline \multirow{2}{*}{ Nunavut $^{\mathrm{i}}$} & \multirow{2}{*}{ Grade 6} & Girls & & & & N/A & N/A & N/A & N/A & N/A & N/A & N/A & N/A & N/A \\
\hline & & Boys & & & & & & & & & & & N/A & $\mathrm{N} / \mathrm{A}$ \\
\hline
\end{tabular}

Three doses 4vHPV; $\square$ Two doses 4vHPV; $\square$ Three doses 9vHPV; $\quad$ Two doses 9vHPV; $\square$ 9vHPV + 2vHPV; N/A, not available. ${ }^{a}$ In 2010, the British Columbia program schedule changed. Girls in Grade 6 in 2010/11 were vaccinated with two doses and received their 3rd and final dose in Grade 9. Girls in Grade 6 in 2011/12 to 2013/14 were scheduled to receive their $3^{\text {rd }}$ dose in Grade 9, but the HPV program changed to two doses in 2014 and, therefore, these girls never received their 3rd dose. ${ }^{b}$ In 2018, the Alberta program schedule changed from Grade 5 to Grade 6 . Vaccination was in Grade 5 from 2008/09 to 2017/2018 and moved to Grade 6 in 2018/19. In 2018, the cohort in Grade 6 had already received the vaccine in Grade 5 ; therefore, no primary cohort was vaccinated for the school year 2018/19. Of note, Alberta reports coverage rates based on school year grade only since 2017/18 school year. Therefore, from therefore, no primary cohort was vaccinated for the school year 2018/19. Of note, Alberta reports coverage rates based on school year grade only since 2017/18 school year. Therefore, from
$2008 / 09$ to 2016/17, coverage rates were calculated based on 3 doses by age of 12; coverage rate might not be comparable year to year. ${ }^{\mathrm{c}}$ In Saskatchewan, vaccination coverage rates are calculated based on age cohorts and not on school grades. Therefore, the coverage rate of a given cohort is available only once they reach a certain age (i.e., 13,15 , or 17 years old). For example, for the cohort vaccinated in Grade 6 in 2016/17, the coverage rate is only available once they reach 13 years old, two years later, in 2018 (assuming they were aged of 11 years old at the time of the vaccine). For cohorts vaccinated in 2008/09 and 2009/10, calculations were based on 3 doses by the age of 15 as these were the only rates available for those cohorts. For cohorts vaccinated in 2010/11 to 2014/15, calculations were based on 3 doses by the age of 13, and for cohorts vaccinated in 2015/16 and 2016/17, calculations were based on 2 doses by the age of 13. ${ }^{\mathrm{d}}$ In Manitoba, vaccination coverage rates are calculated based on age cohorts (i.e., 13 and 17 years old). For cohorts vaccinated from 2008/09 to 2011/12, vaccination coverage rates were calculated at age 17, and for cohorts vaccinated from 2013/14 to 2015/16, vaccination coverage rates were calculated at age 13 . ${ }^{e}$ In 2016 , the Ontario program schedule changed. Vaccination was in Grade 8 from 2007/08 to 2015/16 for females and moved to Grade 7 in 2016/17. As of 2018/19, the coverage rate reported by Ontario combined girls and boys and was $57.9 \% .{ }^{\mathrm{f}}$ From 2008/09 to 2012/13, in Quebec, girls in Grade 4 received two doses of the 4vHPV and were scheduled to receive their 3rd dose in Grade 9. The program changed to two-dose in 2013 and, therefore, girls in Quebec never received the 3rd dose. In 2018, Ouebec moved from 2 doses of the 9vHPV vaccine to a mixed vaccination schedule with one dose of the 9vHPV vaccine and one dose of the $2 \mathrm{vHPV}$ vaccine ${ }^{\mathrm{g}}$ In 2009/10, the Nova Scotia Public Health department was responding to the H1N1 flu pandemic and resources were only available to conduct immunization clinics for one grade level. Therefore, in the 2009/10 school year, Grade 10 students were immunized, and in 2010/11, Grades 7 and 8 were immunized. $\mathrm{h}$ Although Northwest Territories vaccinate girls in Grades 4-6, coverage estimates are conducted in Grade 7. Assume that vaccination was switched to two-dose vaccination schedule in 2016/17 based on Merck \& Co., Inc., Kenilworth, NJ, USA, internal data. Some individuals may have received three doses. ${ }^{i}$ Nunavut program was implemented in March 2010. Assume that vaccination was switched to two-dose vaccination schedule in 2016/17 based on Merck \& Co., Inc., Kenilworth, NJ, USA, internal data. Some individuals may have received three doses. Sources: Provincial health authorities [10-26]. 
Table 2. School-based temporary catch-up HPV vaccination programs.

\begin{tabular}{|c|c|c|}
\hline \multirow{2}{*}{ Province/Territory } & \multicolumn{2}{|c|}{ Cohorts that Were Eligible for School-Based Catch-Up HPV Program } \\
\hline & Girls & Boys \\
\hline British Columbia & $\begin{array}{l}\text { Catch-up in Grade } 9 \text { from 2008/09 to } \\
\text { 2010/11 }\end{array}$ & No catch-up program \\
\hline Alberta & $\begin{array}{l}\text { Catch-up in Grade } 9 \text { from 2009/10 to } \\
\text { 2011/12 }\end{array}$ & $\begin{array}{l}\text { Catch-up in Grade } 9 \text { from 2014/15 to } \\
\text { 2017/18 }\end{array}$ \\
\hline Saskatchewan & Catch-up in Grade 7 in 2008/09 & No catch-up program \\
\hline Manitoba & No catch-up program & $\begin{array}{l}\text { Catch-up in Grades } 8 \text { or } 9 \text { from 2016/17 to } \\
\text { 2018/19 }\end{array}$ \\
\hline Ontario & Catch-up in Grade 8 in 2016/17 ${ }^{\text {a }}$ & No catch-up program \\
\hline Quebec & $\begin{array}{l}\text { Catch-up in Grade } 9 \text { from 2008/09 to } \\
\text { 2012/13 }\end{array}$ & $\begin{array}{l}\text { Catch-up in Grade } 9 \text { from 2018/19 to } \\
\text { 2020/21 }\end{array}$ \\
\hline New Brunswick & $\begin{array}{l}\text { Catch-up in Grade } 8 \text { in 2008/09 } \\
\text { Catch-up in Grade } 8 \text { in 2010/11 b }\end{array}$ & No catch-up program \\
\hline Nova Scotia $^{c}$ & $\begin{array}{l}\text { Catch-up in Grade } 10 \text { in 2009/10 } \\
\text { Catch-up Grade } 8 \text { in 2010/11 }\end{array}$ & No catch-up program \\
\hline Prince Edward Island & No catch-up program & No catch-up program \\
\hline Newfoundland/Labrado & $\begin{array}{l}\text { Catch-up in Grade } 9 \text { from 2008/09 to } \\
2009 / 10\end{array}$ & No catch-up program \\
\hline Yukon & Catch-up in Grades 7 and 8 from 2009/10 & No catch-up program \\
\hline $\begin{array}{c}\text { Northwest Territories } \\
\mathrm{d}\end{array}$ & $\begin{array}{c}\text { Catch-up in Grades } 11 \text { and } 12 \text { in 2009/10 } \\
\text { Catch-up in Grades } 10 \text { and } 11 \text { in 2010/11 } \\
\text { Catch-up in Grades } 9 \text { and } 10 \text { in 2011/12 } \\
\text { Catch-up in Grade } 9 \text { from 2012/13 to } \\
\text { 2014/15 }\end{array}$ & No catch-up program \\
\hline Nunavut & No catch-up program & No catch-up program \\
\hline $\begin{array}{l}\text { a In the 2016/17 schoc } \\
\text { HPV vaccine so that } \mathrm{tl} \\
\text { vaccine was delayed ir } \\
\text { following school year, } \\
\text { because of the H1N1 } \\
\text { flu pandemic and resc } \\
\text { program was already i } \\
\text { The following year, bo } \\
\text { for Northwest Territor } \\
\text { confirmed with officia }\end{array}$ & $\begin{array}{l}\text { year, the program moved from Grade } 8 \text { to } \\
\text { is cohort would not be missed during the tran } \\
\text { some areas of the province because of the H1N } \\
2010 / 11 \text {, the HPV vaccine was offered to female } \\
\text { ampaign. }{ }^{c} \text { In } 2009 / 10 \text {, the Nova Scotia Public } \\
\text { urces were only available to conduct immuniz } \\
\text { t place in Grade } 10 \text { for other vaccines. Therefore } \\
\text { th Grade } 7 \text { (primary cohort) and Grade } 8 \text { were } \\
\text { es was based on the Canada Communicable Dis } \\
\text { s from the Northwest Territories. However, as }\end{array}$ & $\begin{array}{l}\text { Srade } 7 \text {. Girls in Grade } 8 \text { were offered the } \\
\text { sition. b In the } 2009 / 10 \text { school year, the HPV } \\
1 \text { mass immunization campaign. During the } \\
\text { students in Grade } 8 \text {, where delays occurred } \\
\text { Health service was responding to the H1N1 } \\
\text { ation clinics for one grade level. A catch-up } \\
\text { HPV vaccine was offered to girls in Grade } 10 . \\
\text { mmunized (catch-up cohort). }{ }^{d} \text { Information } \\
\text { ease Report and the information could not be } \\
\text { f } 2017 \text {, the province covers HPV vaccination } \\
\text { d provincial health authorities }[17,18,27-30] \text {. }\end{array}$ \\
\hline
\end{tabular}


Table 3. Birth years of children that have been eligible for school-based HPV vaccination programs (as of end of 2019/20 school year).

\begin{tabular}{|c|c|c|c|c|c|c|c|c|c|c|c|c|c|c|c|c|c|c|c|}
\hline \multirow[t]{2}{*}{ Province/Territory } & \multicolumn{19}{|c|}{ Birth Year } \\
\hline & 1992 & 1993 & 1994 & 1995 & 1996 & 1997 & 1998 & 1999 & 2000 & 2001 & 2002 & 2003 & 2004 & 2005 & 2006 & 2007 & 2008 & 2009 & 2010 \\
\hline \multicolumn{20}{|l|}{ British Columbia } \\
\hline \multicolumn{20}{|l|}{ Alberta } \\
\hline \multicolumn{20}{|l|}{ Saskatchewan } \\
\hline \multicolumn{20}{|l|}{ Manitoba } \\
\hline \multicolumn{20}{|l|}{ Ontario } \\
\hline \multicolumn{20}{|l|}{ Quebec } \\
\hline \multicolumn{20}{|l|}{ New Brunswick } \\
\hline \multicolumn{20}{|l|}{ Nova Scotia } \\
\hline \multicolumn{20}{|l|}{ Prince Edward Island } \\
\hline \multicolumn{20}{|l|}{ Newfoundland/Labrador } \\
\hline \multirow{2}{*}{\multicolumn{20}{|c|}{ Yukon }} \\
\hline & & & & & & & & & & & & & & & & & & & \\
\hline Nunavut & & & & & & & & & & & & & & & & & & & \\
\hline
\end{tabular}

Girls only birth cohort; $\square$ Girls and boys birth cohort; $\square$ Temporary catch-up cohort ${ }^{\text {a a }}$ In Quebec, there is currently a temporary catch-up cohort in place and Grade 9 boys will be vaccinated in 2020/21. Sources: Provincial health authorities [10-18,28,30,31].

Table 4. Other groups eligible for public HPV vaccination programs.

\begin{tabular}{|c|c|c|c|c|c|}
\hline & Catch-Up Out of School & MSM & Transgender & HIV & Other High-Risk \\
\hline $\begin{array}{l}\text { British } \\
\text { Colombia }\end{array}$ & $\begin{array}{c}\text { Females born } \geq 1994 \text { and males } \\
\text { born } \geq 2006 \text { who did not get the } \\
\text { vaccine in Grade } 6 \text { remain eligible } \\
\text { if they start their vaccine series } \\
\text { before their } 19 \text { th birthday and } \\
\text { complete it before their } \\
\text { 26th birthday. }\end{array}$ & $\begin{array}{l}\text { Males aged 9-26 } \\
\text { years who: have sex } \\
\text { with other men or } \\
\text { are not yet sexually } \\
\text { active but are } \\
\text { questioning their } \\
\text { sexual orientation. }\end{array}$ & $\begin{array}{l}\text { Transgender } \\
\text { individuals aged } \\
\text { 9-26 years. }\end{array}$ & $\begin{array}{c}\text { HIV positive } \\
\text { individuals aged 9-26 } \\
\text { years. }\end{array}$ & $\begin{array}{c}\text { Males aged 9-26 years who are street involved. } \\
\text { Males aged 9-18 in the care of the Ministry of } \\
\text { Children and Family Development. } \\
\text { Males of any age who are in youth custody } \\
\text { services centres. }\end{array}$ \\
\hline Alberta & $\begin{array}{l}\text { Females and males who were } \\
\text { eligible in Grade } 6 \text { are eligible up } \\
\text { to the age of } 26 .\end{array}$ & $\begin{array}{c}\text { Males aged 17-26 } \\
\text { years. }\end{array}$ & & & $\begin{array}{c}\text { Hematopoietic Stem Cell Transplant recipients } \\
\text { between the ages of } 9 \text { years up to the end of } \\
\text { Grade } 12 . \\
\text { Solid Organ Transplant candidates and } \\
\text { recipients between the ages of 9-26 years. }\end{array}$ \\
\hline
\end{tabular}


Table 4. Cont

\begin{tabular}{|c|c|c|c|c|c|}
\hline & Catch-Up Out of School & MSM & Transgender & HIV & Other High-Risk \\
\hline Saskatchewar & $\begin{array}{c}\text { Females born } \geq 1994 \text { and males } \\
\text { born } \geq 2006 \text { are eligible up to the } \\
\text { age of } 26 \text {. }\end{array}$ & & & $\begin{array}{l}\text { Individuals aged 9-26 } \\
\text { years. }\end{array}$ & $\begin{array}{l}\text { Immunocompromised individuals aged 9-26 } \\
\text { years. }\end{array}$ \\
\hline Manitoba & $\begin{array}{l}\text { Females born } \geq 1997 \text { and males } \\
\text { born } \geq 2002\end{array}$ & $\begin{array}{l}\text { Males aged } 9-26 \\
\text { years who identify } \\
\text { as gay or bisexual. }\end{array}$ & $\begin{array}{c}\text { Transgender } \\
\text { individuals aged } \\
\text { 9-26 years. }\end{array}$ & $\begin{array}{l}\text { Immunocompetent } \\
\text { HIV-infected females } \\
\text { aged 9-45 years. } \\
\text { Immunocompetent } \\
\text { HIV-infected males } \\
\text { aged 9-26 years. }\end{array}$ & $\begin{array}{c}\text { Females aged } 9-45 \text { years and males aged 9-26 } \\
\text { years who have congenital or acquired immune } \\
\text { deficiencies. } \\
\text { Males aged } \leq 18 \text { years who are, or who have } \\
\text { ever been, incarcerated.Individuals with } \\
\text { recurrent respiratory papillomatosis. } \\
\text { Females aged 9-45 years who have a newly } \\
\text { diagnosed high-grade cervical histopathology } \\
\text { result. } \\
\text { Females aged 9-45 years and males aged 9-26 } \\
\text { years who are victims of sexual assault. } \\
\text { Patients currently under the care of a } \\
\text { hematologist or oncologist who have malignant } \\
\text { neoplasms or have completed } \\
\text { immunosuppressive therapy or hypo- } \\
\text { or asplenic. }\end{array}$ \\
\hline Ontario & $\begin{array}{l}\text { Females and males are eligible to } \\
\text { initiate or complete the series } \\
\text { until the end of their Grade } 12 \\
\text { year, if previously eligible for the } \\
\text { Grade } 7 \text { or } 8 \text { programs. }\end{array}$ & Males $\leq 26$ years. & $\begin{array}{c}\text { Individuals } \leq 26 \\
\text { years. }\end{array}$ & & \\
\hline Quebec & $\begin{array}{c}\text { Females }<18 \text { years at their } \\
\text { first dose. } \\
\text { Males who have completed } \\
\text { Grade } 4 \text { since } 2016 / 17 .\end{array}$ & Males $\leq 26$ years. & & Individuals $\leq 26$ years. & $\begin{array}{c}\text { Males aged } 9-17 \text { years who attend rehabilitation } \\
\text { centres for youth in difficulty, who are under the } \\
\text { care of youth protection services, or who are } \\
\text { homeless. } \\
\text { Individuals } \leq 26 \text { years who have weakened } \\
\text { immune system. }\end{array}$ \\
\hline $\begin{array}{l}\text { New } \\
\text { Brunswick }\end{array}$ & $\begin{array}{c}\text { Females born } \geq 1995 \text { and males } \\
\text { born } \geq 2005 \text { are eligible up to the } \\
\text { age of } 26 .\end{array}$ & & & & \\
\hline
\end{tabular}


Table 4. Cont

\begin{tabular}{|c|c|c|c|c|c|}
\hline & Catch-Up Out of School & MSM & Transgender & HIV & Other High-Risk \\
\hline $\begin{array}{l}\text { Nova } \\
\text { Scotia }\end{array}$ & $\begin{array}{l}\text { Females and males who have } \\
\text { missed or refused HPV vaccine as } \\
\text { part of the school-based program } \\
\text { (beginning September } 2015 \text { in } \\
\text { male) up to and including } 18 \\
\text { years of age. }\end{array}$ & Males $\leq 45$ years. & & Individuals $\leq 45$ years. & \\
\hline $\begin{array}{l}\text { Prince } \\
\text { Edward } \\
\text { Island }\end{array}$ & $\begin{array}{l}\text { Females and males are eligible if } \\
\text { missed HPV immunization in } \\
\text { Grade } 6 \text { (since } 2007 \text { for females } \\
\text { and } 2012 \text { for males). }\end{array}$ & $\begin{array}{l}\text { All eligible } \\
\text { individuals } \\
\text { regardless of age. }\end{array}$ & & $\begin{array}{c}\text { All eligible } \\
\text { individuals regardless } \\
\text { of age. }\end{array}$ & $\begin{array}{c}\text { Females aged } 18-45 \text { years and males aged } 18-26 \\
\text { years who have unprotected sex with multiple } \\
\text { partners, a history of genital warts, or an } \\
\text { abnormal PAP test (female only). }\end{array}$ \\
\hline \multicolumn{6}{|c|}{$\begin{array}{cc} & \text { Females and males who were } \\
\text { Newfoundland/igible in Grade } 6 \text { are eligible } \\
\text { until the person leave the school } \\
\text { Labrador } \\
\text { system (males in Grade } 6 \text { are } \\
\text { eligible as of September 2017). }\end{array}$} \\
\hline Yukon & $\begin{array}{c}\text { Females and male who were } \\
\text { eligible in Grade } 6 \text { (starting in } \\
\text { school year 2011/12 in female and } \\
\text { in 2017/18 in male).Females up to } \\
18 \text { years of age at time of first } \\
\text { dose. }\end{array}$ & Males $\leq 26$ years & & Individuals $\leq 45$ years. & Street involved males $\leq 26$ years. \\
\hline $\begin{array}{l}\text { Northwest } \\
\text { Territories }\end{array}$ & $\begin{array}{l}\text { Females and males are eligible up } \\
\text { to the age of } 26 .\end{array}$ & & & & Females and males up to 26 years of age. \\
\hline Nunavut & $\begin{array}{l}\text { Females and males who would } \\
\text { have been in Grade } 6 \text { in the } \\
\text { 2017/18 school year or later are } \\
\text { eligible until Grade } 12 .\end{array}$ & & & & \\
\hline
\end{tabular}




\subsection{HPV Vaccination Coverage Rates in School-Based Programs}

Time trends in HPV vaccination coverage rates (full course) in schoolgirls from 2007/08 to 2018/19 are shown in Figure 2. Rates in girls ranged from $48 \%$ in Ontario in the first year of the program to $94 \%$ in Newfoundland/Labrador in 2012/13. Only Prince Edward Island had rates consistently over $80 \%$ : in girls in years $2011 / 12$ to $2018 / 19$ and in boys in $2014 / 15$ to $2018 / 19$. Rates were over $80 \%$ in Nova Scotia in boys in 2015/16 and 2016/17. For some provinces (Alberta, Ontario), there is evidence that rates gradually increased over the first several years of the program, while in Newfoundland/Labrador, rates improved consistently over the entire time period. In Saskatchewan, rates in girls declined gradually over the time period, from $75 \%$ in $2008 / 09$ to $69 \%$ in $2016 / 17$. There is no obvious time trend in the remaining provinces.

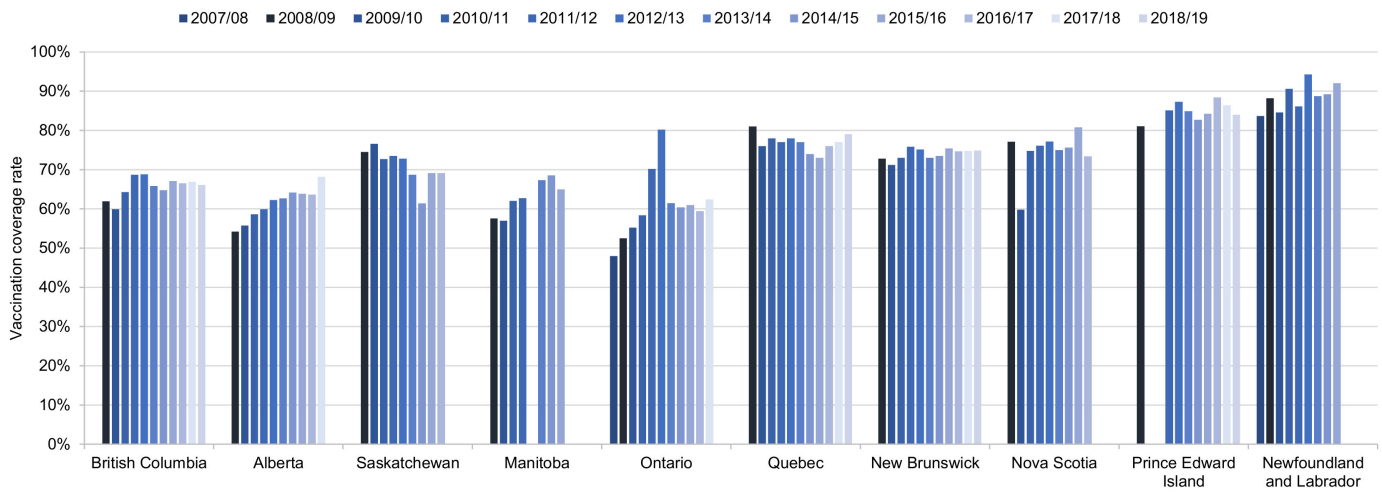

Figure 2. Time trends in HPV vaccination coverage rates in schoolgirls in school years 2007/08 to 2018/19 in the 10 provinces with data. Vaccination coverage rates are reported for full course of treatment at the time of the vaccination. Vaccination coverage rates may not be comparable across provinces as each province used its own methodology. Source: Canadian Partnership Against Cancer System Performance and provincial health authorities [10,12,13,15,17,19-21,31,37-39].

The most recent HPV vaccination coverage rates (in 2016/17, 2017/18, or 2018/19) in school children are shown in Figure 3. The highest rates occur in Prince Edward Island in girls (84\%) and boys (82\%), and Nova Scotia (boys only, 85\%).

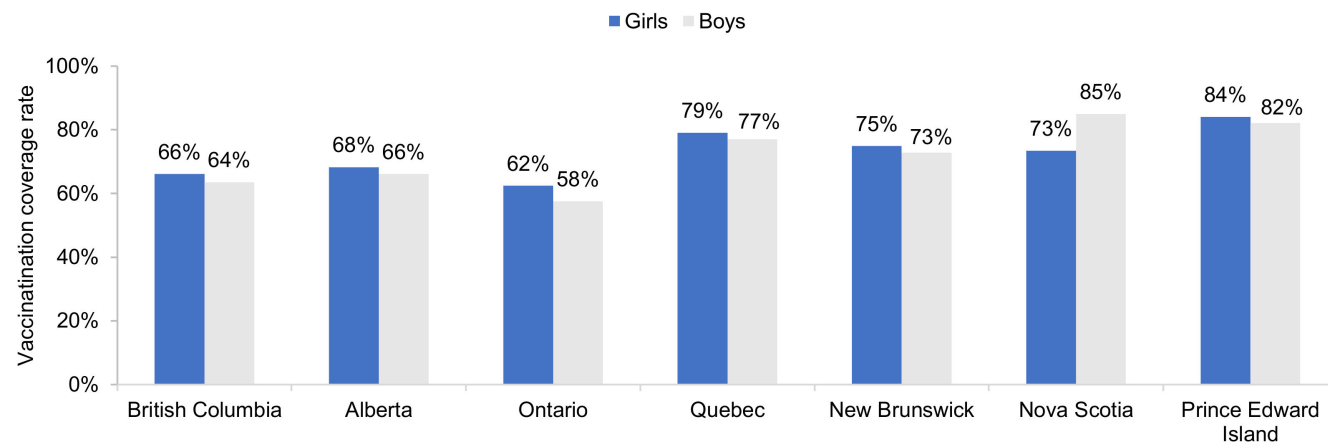

Figure 3. Most recent HPV vaccination coverage rates in schoolgirls and schoolboys, by province. Shown are the most recent data only for provinces with vaccination of both girls and boys. Data are for 2016/17 for Nova Scotia. Data are for 2017/18 for Alberta and Ontario. Data are for 2018/19 for British Columbia, Quebec, New Brunswick, and Prince Edward Island. Source: Canadian Partnership Against Cancer System Performance and provincial health authorities [10-20,23,36,37,39].

\section{Discussion}

Since their introduction in 2007, Canadian publicly funded HPV vaccination programs have evolved generally from a three-dose to a two-dose schedule, from a quadrivalent to a nonavalent 
vaccine, and from a girls-only to a gender-neutral program. HPV programs have been shown to be effective, resulting in decline in the incidence of pre-cancerous cervical lesions and genital warts in Canada [40].

In addition to the school-based programs, in most jurisdictions, individuals who missed the full course while at school remained eligible for a certain period of time to receive publicly funded HPV vaccine. Research has shown that providing opportunities to receive missed doses in schools through catch-up programs is important in optimizing coverage [6].

Most jurisdictions have enhanced their public HPV vaccination programs to include high-risk groups, such as men who have sex with men, transsexual persons, HIV-infected individuals, and other at-risk groups. However, there is no standardization and programs vary across provinces and territories.

The transition to a mixed HPV vaccine dose schedule in Quebec in the fall of 2018 has been widely debated, stemming from the limited clinical efficacy data of this schedule before adoption [41-44]. To date, no other jurisdiction in the world has adopted a mixed dose schedule [45]. Following COVID-19 disruptions to school-based vaccine delivery in September 2020, the schedule was further modified to include a deferral of the second dose to 5 years after the first dose. In the absence of long-term durability and/or effectiveness data, the real-world impact of this schedule on HPV-related outcomes in these cohorts may not be fully understood for at least a decade [41].

The current COVID-19 pandemic has disrupted many immunization activities across Canada. School closings, originated from the need to control viral transmission, and disruptions from competing priorities in the capacity of the public health system have led to a decrease in coverage in the school-based programs. Provincial surveillance mechanisms are currently assessing the extent of the vaccination delays and losses in coverage [45].

Despite the challenges imposed by its large land area (the second largest country in the world), sparsely populated rural areas, and lack of a central coordinating authority for overseeing immunization delivery, Canadian HPV vaccination programs have largely succeeded, relative to other high-income countries. However, current vaccine coverage rates fall short of the Canadian Partnership Against Cancer (CPAC)'s target to eliminate cervical cancer by 2040. CPAC's recommendations include attaining: $90 \%$ of 17 -year-olds to be fully vaccinated by $2025 ; 90 \%$ of eligible women to have been screened with an HPV test by 2030; and 90\% of all women with an abnormal screening result to receive within 3 months appropriate diagnostic and treatment by 2030 [46].

Vaccination coverage rates have varied markedly by jurisdiction, and there have been no consistent time trends. Irrespective of jurisdiction, coverage rates in schoolboys have been similar to those in schoolgirls. Since the 2012/13 school year, only Nova Scotia, Prince Edward Island, and Newfoundland/Labrador have had vaccination coverage rates exceeding $80 \%$ in any school year. The recommendations of the Canadian Immunization Committee, that $80 \%$ of eligible schoolgirls receive the required doses of HPV vaccine within 2 years and 90\% within 5 years of program introduction, have largely not been met [47]. More recently, the public health national immunization goal is to achieve by 2025 90\% vaccination coverage (two or more doses of HPV vaccine) by 17 years of age in all adolescents [48].

Provinces with the same vaccination program evolution-e.g., Saskatchewan, Ontario, New Brunswick, and Prince Edward Island-have widely different coverage rates. There is no clear evidence that a change in the number of doses was associated with changes in vaccination coverage. There are eight jurisdictions that switched from a three-dose to a two-dose strategy and in only two of them was there a more than five percent increase in vaccination coverage: Saskatchewan and Nova Scotia, both in 2014/2015 to 2016/2017. Similarly, switching the vaccine (but maintaining the same number of doses) had no apparent effect on vaccination coverage. There were six instances of switching the vaccine while maintaining a two-dose schedule and in no instance was there a change in vaccination coverage of $\geq 5 \%$.

Gilbert et al. (2016) explored determinants of HPV non-vaccination and vaccine refusal in girls 12-14 years old, based on data from the Childhood National Immunization Coverage Survey 
of 2013 [49]. Among sociodemographic variables, a younger age (12 years) at vaccination and a European country of birth of the responding parent were associated with an increased risk of not being vaccinated, while parental knowledge, attitudes, and beliefs were associated with parental refusal of HPV vaccination [49].

A 2014 study of a nationally representative sample of Canadian parents of boys aged 9-16 examined psychosocial factors in parents' HPV vaccine decision-making for their son [50,51]. Grounded in the Precaution Adoption Process Model, results from the online survey illustrated that discussion with a healthcare provider about the HPV vaccine, higher HPV knowledge, increased perception of risks in the absence of HPV vaccination or that others endorse HPV vaccination, and positive attitudes related to vaccines in general were associated with increased odds of being in the more advanced stages of the decision to vaccinate their son. Believing that HPV vaccination is harmful increased the odds of deciding not to vaccinate while perceiving the benefits of HPV vaccination decreased the odds [50].

More recently, Tatar et al. (2019) examined parental HPV vaccine hesitancy from a nationally representative sample of Canadian parents of 9-16 years old boys and girls in 2016 and 2017 [52]. HPV-related attitudes, behaviors, knowledge, and intentions to vaccinate changed over time in parents categorized as "flexible" hesitant (unengaged/undecided) compared to "rigid" hesitant (decided not). Higher social influence, HPV knowledge, and family income, white race, and lower perception of harms (vaccine safety) were associated with higher HPV vaccine acceptability in "flexible" hesitant parents. Given that healthcare in Canada is managed by the individual provinces and territories, there is substantial variation in the delivery and administration of the HPV vaccine across the 13 different programs [6].

Vaccine coverage rates and type of service delivery model may also be impacted by the diverse geography and contextual means of delivery across the Canadian landscape. In Calgary, Alberta, during the period 2008-11, the HPV vaccine was offered free of charge to all girls in Grades 5 and 9 , with two different service delivery models, depending upon the acceptance of the program by the local school board-immunization against HPV was not permitted in-school in the Calgary Catholic School District and at a small number of private schools, and in these cases, vaccination was provided in the community at Public Health Clinics [53]. HPV vaccination completion rates were much higher for girls with an in-school model than for girls with a community service model (75\% versus 36\%) [53,54].

Bird et al. (2017) reported a meta-analysis of vaccine uptake rates in six of the Canadian provinces based on 12 studies published in the period 2010-2016 [55]. Rates of vaccine uptake varied by age, sex, service delivery model, and funding source. Rates in those $\leq 18$ versus $>18$ years old were $67 \%$ versus $14 \%$, in female versus male (57\% versus $47 \%$ ), in school-based versus community-based programs (69\% versus 19\%), and with public funding versus out-of-pocket payment (67\% versus $14 \%$ ).

Many countries in Europe and the Americas included HPV vaccination of adolescents in their national immunization programs, beginning in 2007 [56]. These programs differ in service delivery method (school- or clinic-based), public funding, inclusion of catch-up vaccination, etc. [56]. However, programs in some countries are similar to those in Canada. For instance, Australia implemented publicly funded, school-based HPV vaccination in 2007, targeting females 12-13 years of age, with catch-up vaccination, and extending the program in 2013 to include males [57]. As of 2015, estimated coverage with three doses was $77 \%$ for females and $66 \%$ for males [57]. Scotland initiated a similar program, but without including males, and achieved a three-dose coverage rate in the target cohort (12-13-year-old females) of 90\% [58]. HPV vaccination programs in most countries, however, are clinic-based [56]. Notably, the United States initiated clinic-based HPV vaccination in 2006, targeting females 11-12 years, and adding males 11-12 years in 2011 [57]. As of 2015, estimated coverage with at least one dose was only $42 \%$ among females and $10 \%$ among males $19-26$ years of age [58].

\section{Limitations}

The present study is limited in that there are gaps in the available information. Not all HPV vaccine coverage rates have been reported for all years, age, and sex by each jurisdiction in Canada. 
Coverage in other eligible groups outside school-based is rarely available. Canada does not have a national vaccination surveillance program; therefore, there is a lack of standardized methodologies for reporting vaccination coverage rates across jurisdictions, making it difficult to compare vaccination rates $[6,59]$. We reported the vaccine coverage rates as provided by provincial health authorities and did not investigate the methodology employed by each individual health unit.

\section{Conclusions}

In conclusion, since their implementation in schoolgirls in 2007, provincial and territorial programs have undergone multiple policy changes, gradually increasing population protection via inclusion of boys and high-risk groups. Over time, policy changes have reflected the evolving science of HPV vaccination and funding support. While there are methodological variations across jurisdictions in how data are collected and reported, HPV vaccination rate targets clearly remain to be met in the school-based public programs in Canada. The data collated in this report may assist Canadian health authorities in addressing the shortfall in HPV vaccination coverage, with the eventual goal of eliminating HPV-related cervical and other cancers.

Supplementary Materials: The following are available online at http://www.mdpi.com/1718-7729/28/1/97/s1, Table S1: PICO (+) framework.

Author Contributions: A.G., G.P.Y., V.R., P.B., and S.K. contributed to the conception, design, acquisition, analysis, or interpretation of the data and drafting or revising the manuscript critically for important intellectual content. E.L.F. contributed to the conception, design, and interpretation of the data and revised the manuscript critically for important intellectual content. All authors have read and agreed to the published version of the manuscript.

Funding: The study was funded by Merck Sharp \& Dohme Corp., a subsidiary of Merck \& Co., Inc., Kenilworth, NJ, USA.

Institutional Review Board Statement: Not applicable.

Informed Consent Statement: Not applicable.

Data Availability Statement: Data were extracted from governmental databases and statistics, informal reports, Embase, and PubMed. Data are publicly available.

Acknowledgments: The authors thank ScribCo for medical writing assistance.

Conflicts of Interest: We have read and understood Current Oncology's policy on disclosing conflicts of interest and declare the following interests: AG, VR, and PB are employees of Merck Canada Inc., Kirkland, QC, Canada. GPY and SK are employees of Merck Sharp \& Dohme Corp., a subsidiary of Merck \& Co., Inc. Kenilworth, NJ, USA and may own stock in Merck \& Co., Inc., Kenilworth, NJ, USA. ELF has served as occasional advisor to companies involved with HPV vaccination (Merck \& Co., Inc. and GlaxoSmithKline) and HPV diagnostics (Roche and Becton Dickinson). His institution has received unconditional grants from Merck \& Co., Inc. and Roche in support of research that he initiated at McGill University.

\section{References}

1. Forman, D.; De Martel, C.; Lacey, C.J.; Soerjomataram, I.; Lortet-Tieulent, J.; Bruni, L.; Vignat, J.; Ferlay, J.; Bray, F.; Plummer, M.; et al. Global Burden of Human Papillomavirus and Related Diseases. Vaccine 2012, 30, F12-F23. [CrossRef] [PubMed]

2. Burd, E.M. Human Papillomavirus and Cervical Cancer. Clin. Microbiol. Rev. 2003, 16, 1-17. [CrossRef] [PubMed]

3. Bouvard, V.; Baan, R.; Straif, K.; Grosse, Y.; Secretan, B.; El Ghissassi, F.; Benbrahim-Tallaa, L.; Guha, N.; Freeman, C.; Galichet, L.; et al. A review of human carcinogens-Part B: Biological agents. Lancet Oncol. 2009, 10, 321-322. [CrossRef]

4. Smith, M. HPV related cancers: Tip of a very large iceberg! J. Fam. Pract. Oncol. 2017, $29,1$.

5. Saraiya, M.; Steben, M.; Watson, M.; Markowitz, L. Evolution of cervical cancer screening and prevention in United States and Canada: Implications for public health practitioners and clinicians. Prev. Med. 2013, 57, 426-433. [CrossRef]

6. Shapiro, G.K.; Guichon, J.; Kelaher, M. Canadian school-based HPV vaccine programs and policy considerations. Vaccine 2017, 35, 5700-5707. [CrossRef] [PubMed] 
7. Rogers, C.; Smith, S.R. Examining Provincial HPV Vaccination Schemes in Canada: Should We Standardise the Grade of Vaccination or the Number of Doses? Int. Sch. Res. Not. 2015, 2015, 1-16. [CrossRef]

8. Smith, A.; Baines, N.; Memon, S.; Fitzgerald, N.; Chadder, J.; Politis, C.; Nicholson, E.; Earle, C.; Bryant, H. Moving toward the elimination of cervical cancer: Modelling the health and economic benefits of increasing uptake of human papillomavirus vaccines. Curr. Oncol. 2019, 26, 80-84. [CrossRef]

9. Shapiro, G.K.; Perez, S.; Rosberger, Z. Including males in Canadian human papillomavirus vaccination programs: A policy analysis. Can. Med. Assoc. J. 2016, 188, 881-886. [CrossRef]

10. BC Centre for Disease Control. Immunization Uptake in Grade 6 Students; BC Centre for Disease Control: Vancouver, BC, Canada, 2018.

11. Government of Saskatchewan. Vaccine Preventable Disease Monitoring Report: Human Papillomavirus, 2017; Population Health Branch: Regina, SK, Canada, 2018.

12. Ontario Agency for Health Protection and Promotion (Public Health Ontario). Immunization Coverage Report for School Pupils: 2016-17 School Year; Queen's Printer for Ontario: Toronto, ON, Canada, 2018.

13. New Brunswick Department of Health. Daycare, School Entry, and School Program Immunization Report. Data for School Year 2017/18; New Brunswick Department of Health: Fredericton, NB, Canada, 2018.

14. Alberta Health. Interactive Health Data Application 2019. Available online: http://www.ahw.gov.ab.ca/ IHDA_Retrieval/ihdaData.do (accessed on 29 August 2019).

15. Prince Edward Island Provincial Immunization Committee Chief Public Health Office. Childhood Immunization in PEI 2017. Available online: https:/www.princeedwardisland.ca/sites/default/files/ publications/childhoodreportfinal.pdf (accessed on 4 September 2019).

16. Government of Quebec. Flash Vigie Bulletin Quebecois de Vigie, de Surveillance et D'intervention en Protection de la sante Publique; Government of Quebec: Montréal, QC, Canada, 2015; pp. 1-3.

17. Prince Edward Island. Human Papillomavirus (HPV) Vaccine (Gardasil ${ }^{\circledR}$ 9) $2018 . \quad$ Available online: https://www.princeedwardisland.ca/en/information/health-and-wellness/human-papillomavirushpv-vaccine-gardasilr-9 (accessed on 4 September 2019).

18. Newfoundland Labrador. Communicable Disease Report; Newfoundland Labrador Health and Community Services: St. John's, NL, Canada, 2015.

19. Canadian Partnership Against Cancer. The 2016 Cancer System Performance Report; Canadian Partnership Against Cancer: Toronto, ON, Canada, 2016.

20. Canadian Partnership Against Cancer. The 2018 Cancer System Performance Report; Canadian Partnership Against Cancer: Toronto, ON, Canada, 2018.

21. Canadian Immunization Committee. Recommendations for Human Papillomavirus Immunization Programs; Public Health Agency of Canada: Ottawa, ON, Canada, 2014.

22. Prince Edward Island Population Health Assessment and Surveillance. Immunization Uptake in Grade 6-2017/18; Prince Edward Island Provincial Immunization Committee: Charlottetown, PE, Canada, 2019.

23. BC Centre for Disease Control. Immunization Uptake in Grade 6 Students; BC Centre for Disease Control: Vancouver, BC, Canada, 2019; p. 20.

24. New Brunswick Department of Health. Daycare, School Entry, and School Program Immunization Report. Data for School Year 2018/19; New Brunswick Department of Health: Fredericton, NB, Canada, 2019.

25. Government of Quebec. Flash Vigie Bulletin Quebecois de Vigie, de Surveillance et D'intervention en Protection de la sante Publique; Government of Quebec: Montreal, QC, Canada, 2017; pp. 1-4.

26. Community Health Programs Yukon Immunization Program. Yukon Immunization Program Manual; Government of Yukon, Yukon Immunization Program: Whitehorse, YT, Canada, 2019.

27. BC Centre for Disease Control. Immunize BC: Progress Report: April 1, 2007-March 31, 2012; Ministry of Health: Victoria, BC, Canada, 1 April 2012.

28. Alberta Health Services. Human Papillomavirus 9-Valent Vaccine Biological Page; Alberta Health Services: Calgary, AB, Canada, 2019.

29. Dawar, M.; Harris, M.T.; McNeil, S.; Naci, A.B. Update on Human Papillomavirus (HPV) Vaccines. Can. Commun. Dis. Rep. 2012, 38, 1-62. [CrossRef]

30. Manitoba Health. Manitoba's Immunization Program: Vaccines Offered Free-of-Charge (Eligibility Criteria for Publicly-Funded Vaccines) 2019. Available online: http://www.manitoba.ca/health/publichealth/cdc/ vaccineeligibility.html (accessed on 2 October 2019). 
31. BC Centre for Disease Control. Human Papillomavirus Vaccine [Bivalent (Types 16 and 18) Recombinant]: CERVARIX ${ }^{\circledR}$ 2016. Available online: http://www.bccdc.ca/resource-gallery/Documents/Guidelines\%20and\% 20Forms/Guidelines\%20and\%20Manuals/Epid/CD\%20Manual/Chapter\%202\%20-\%20Imms/Part4/HPV2. pdf (accessed on 29 August 2019).

32. BC Centre for Disease Control. Immunize BC: Evidence-Based Immunization Information and Tools for B.C. Residents. Available online: https://immunizebc.ca/hpv (accessed on 29 August 2019).

33. Nunavut Department of Health. Nunavut Immunization Manual; Nunavut Department of Health: Iqaluit, NU, Canada, 2017.

34. Nova Scotia Department Health and Wellness. Publicly Funded Vaccine/Immunoglobulin Eligibility Policy 2019. Available online: https://novascotia.ca/dhw/cdpc/documents/Nova_Scotia_Vaccine_Immunoglobin_ eligibility.pdf (accessed on 6 November 2019).

35. Ontario Agency for Health Protection and Promotion (Public Health Ontario). Human Papillomavirus (HPV) Vaccine; Queen's Printer for Ontario: Toronto, ON, Canada, 2017.

36. Nova Scotia Department Health and Wellness. School-Based Immunization Coverage in Nova Scotia, 2016-2017; Nova Scotia Department of Health and Wellness: Halifax, NS, Canada, 2018.

37. Government of Quebec. Flash Vigie Bulletin Quebecois de Vigie, de Surveillance et D'intervention en Protection de la Sante Publique; Government of Quebec: Montréal, QC, Canada, 2018; Volume 13, pp. 1-5.

38. Population Health Branch. Saskatchewan Ministry of Health. Vaccine Preventable Disease Monitoring Report. Human Papillomavirus, 2017; Saskatchewan Ministry of Health: Regina, SK, Canada, 2018.

39. Canadian Partnership Against Cancer. Human Papillomavirus (HPV) Vaccination. Available online: https://www.systemperformance.ca/cancer-control-domain/prevention/hpv-vaccination/\#!figures (accessed on 29 August 2019).

40. Steben, M.; Thompson, M.T.; Rodier, C.; Mallette, N.; Racovitan, V.; DeAngelis, F.; Stutz, M.; Rampakakis, E. A Review of the Impact and Effectiveness of the Quadrivalent Human Papillomavirus Vaccine: 10 Years of Clinical Experience in Canada. J. Obstet. Gynaecol. Can. 2018, 40, 1635-1645. [CrossRef]

41. Rosberger, Z.; Steben, M.; Norris, T.; McFadyen, A.; Shapiro, G.K. A mixed two-dose vaccination schedule: Not enough evidence to support a policy change in Quebec. Vaccine 2019, 37, 4421. [CrossRef]

42. Gilca, V.; Sauvageau, C.; Panicker, G.; De Serres, G.; Ouakki, M.; Unger, E.R. Immunogenicity and safety of a mixed vaccination schedule with one dose of nonavalent and one dose of bivalent HPV vaccine versus two doses of nonavalent vaccine-A randomized clinical trial. Vaccine 2018, 36, 7017-7024. [CrossRef] [PubMed]

43. Franco, E. Quebec's Mixed Schedule in HPV Vaccination Program-Preamble. Available online: https: //www.hpvworld.com/articles/quebec-s-mixed-schedule-in-hpv-vaccination-program-preamble/ (accessed on 27 January 2021).

44. Franco, E. Interview Eduardo Franco. Available online: https://www.hpvworld.com/articles/intervieweduardo-fanco/ (accessed on 27 January 2021).

45. Government of Canada. Interim Guidance on Continuity of Immunization Programs during the COVID-19 Pandemic. Available online: https:/www.canada.ca/en/public-health/services/immunization/nationaladvisory-committee-on-immunization-naci/interim-guidance-immunization-programs-during-covid-19pandemic.html\#a6 (accessed on 27 January 2021).

46. Canadian Partnership Against Cancer. Action Plan for the Elimination of Cervical Cancer in Canada 2020-2030. Available online: https://s22438.pcdn.co/wp-content/uploads/2020/11/Elimination-cervicalcancer-action-plan-EN.pdf (accessed on 27 January 2021).

47. Canadian Immunization Committee. Recommendations on a Human Papillomavirus Immunization Program; Public Health Agency of Canada: Ottawa, ON, Canada, 2007.

48. Government of Canada. Vaccination Coverage Goals and Vaccine Preventable Disease Reduction Targets by 2025. 2020. Available online: https:/www.canada.ca/en/public-health/services/immunization-vaccinepriorities/national-immunization-strategy/vaccination-coverage-goals-vaccine-preventable-diseasesreduction-targets-2025.html\#1.2 (accessed on 27 January 2021).

49. Gilbert, N.L.; Gilmour, H.; Dubé, Ė.; Wilson, S.E.; Laroche, J. Estimates and determinants of HPV non-vaccination and vaccine refusal in girls 12 to $14 \mathrm{y}$ of age in Canada: Results from the Childhood National Immunization Coverage Survey, 2013. Hum. Vaccines Immunother. 2016, 12, 1484-1490. [CrossRef] 
50. Perez, S.; Tatar, O.; Gilca, V.; Shapiro, G.K.; Ogilvie, G.; Guichon, J.R.; Naz, A.; Rosberger, Z. Untangling the psychosocial predictors of HPV vaccination decision-making among parents of boys. Vaccine 2017, 35, 4713-4721. [CrossRef]

51. Perez, S.; Tatar, O.; Shapiro, G.K.; Dubé, E.; Ogilvie, G.; Guichon, J.; Gilca, V.; Rosberger, Z. Psychosocial determinants of parental human papillomavirus (HPV) vaccine decision-making for sons: Methodological challenges and initial results of a pan-Canadian longitudinal study. BMC Public Health 2016, 16, 1223. [CrossRef]

52. Tatar, O.; Shapiro, G.K.; Perez, S.; Wade, K.; Rosberger, Z. Using the precaution adoption process model to clarify human papillomavirus vaccine hesitancy in canadian parents of girls and parents of boys. Hum. Vaccines Immunother. 2019, 15, 1803-1814. [CrossRef]

53. Musto, R.; Siever, J.E.; Johnston, J.C.; Seidel, J.; Rose, M.S.; McNeil, D.A. Social equity in Human Papillomavirus vaccination: A natural experiment in Calgary Canada. BMC Public Health 2013, 13, 640. [CrossRef] [PubMed]

54. Guichon, J.R.; Mitchell, I.; Buffler, P.; Caplan, A. Citizen intervention in a religious ban on in-school HPV vaccine administration in Calgary, Canada. Prev. Med. 2013, 57, 409-413. [CrossRef] [PubMed]

55. Bird, Y.; Obidiya, O.; Mahmood, R.; Nwankwo, C.; Moraros, J. Human papillomavirus vaccination uptake in Canada: A systematic review and meta-analysis. Int. J. Prev. Med. 2017, 8, 71. [CrossRef] [PubMed]

56. Markowitz, L.E.; Tsu, V.; Deeks, S.L.; Cubie, H.; Wang, S.A.; Vicari, A.S.; Brotherton, J.M. Human Papillomavirus Vaccine Introduction-The First Five Years. Vaccine 2012, 30, F139-F148. [CrossRef] [PubMed]

57. Lee, L.-Y.; Garland, S.M. Human papillomavirus vaccination: The population impact. F1000Research 2017, 6, 866. [CrossRef]

58. Williams, W.W.; Lu, P.-J.; O’Halloran, A.; Kim, D.K.; Grohskopf, L.A.; Pilishvili, T.; Skoff, T.H.; Nelson, N.P.; Harpaz, R.; Markowitz, L.E.; et al. Surveillance of Vaccination Coverage among Adult Populations—United States, 2015. MMWR. Surveill. Summ. 2017, 66, 1-28. [CrossRef] [PubMed]

59. Wilson, S.; Quach, S.; Macdonald, S.E.; Naus, M.; Deeks, S.L.; Crowcroft, N.S.; Mahmud, S.M.; Tran, D.; Kwong, J.; Tu, K.; et al. Methods used for immunization coverage assessment in Canada, a Canadian Immunization Research Network (CIRN) study. Hum. Vaccines Immunother. 2017, 13, 1928-1936. [CrossRef] [PubMed]

Publisher's Note: MDPI stays neutral with regard to jurisdictional claims in published maps and institutional affiliations.

(C) 2021 by the authors. Licensee MDPI, Basel, Switzerland. This article is an open access article distributed under the terms and conditions of the Creative Commons Attribution (CC BY) license (http://creativecommons.org/licenses/by/4.0/). 